ISSN: 2641-1725

\title{
The World Politics of Dominique Moisi
}

\author{
Thomas Scheff* \\ Department of Health Services, University of California, USA
}

Received: 眥August 17, 2018; Published: 制 August 23, 2018

*Corresponding author: Thomas Scheff, Department of Health Services, University of California, 3009 Lomita Road Santa Barbara CA, USA

\section{Mini Review}

In his recent (2009) book, The Geopolitics of Emotion, D. Moisi, a French political scientist, took a still somewhat unusual approach; emotions can be causal in political relationships. The book argues indeed that they may be causes of both peace and war between and within nations. He focuses on three emotions: hope, fear, and humiliation. Surprisingly, the book has received a torrent of praise from reviewers. The overwhelmingly positive response to the book is surprising because modern societies play down emotions as unimportant, even between individuals, much less nations. Most persons, even many researchers, take a materialistic stance: emotions are unimportant because both individuals and nations guide their actions toward owning money, land, resources, and other clearly visible materials. It might be that in order to write persuasively about a specific emotion, the readers must first be dissuaded from their fixed idea: emotions are unimportant [1-4].

How did Moisi deal with this idea? There are three parts to his solution. First, rather than focusing on a single emotion, as most emotion researchers do, he considered three: fear, hope, and humiliation. Since one of the three, hope, is positive, the reader probably feels somewhat reassured by its inclusion, even if she or he has an inclination to reject emotions in general. The second emotion, fear, is not positive, but there is less confusion about it than with the emotion discussed below. The third step is more complex. In choosing the word humiliation, Moisi avoids a substantial difficulty that has long ruled the response to one particular emotion. The term humiliation usually refers to the emotion of shame, without using the term that is frequently avoided; people seem ashamed of shame. Just as research on sexual act avoids the f-word, acceptable conversation and most talk and writing about shame avoid the s-word.

The psychologist Gershen Kaufman [5] is one of several who have argued that shame is taboo in modern societies:

American society is a shame-based culture, but ...shame remains hidden. Since there is shame about shame, it remains under taboo ...The taboo on shame is so strict ...that we behave as if shame does not exist. Shame, or the anticipation of shame, is virtually omnipresent for most people, especially secret shame. The idea that people spend much of their time and energy involved in or avoiding shame, if possible, and managing it if not successful, was central to the best known of Erving Goffman's books:

“...there is no interaction in which participants do not take an appreciable chance of being slightly embarrassed or a slight chance of being deeply humiliated." (1959, p. 243, emphasis added).

If this sentence is taken literally, it means that shame and/or the anticipation of shame haunts all social interaction. Avoidance of shame/embarrassment/humiliation is the driving force behind Goffman's phrase "impression management", which at first sight seems to be the central concept thru-out the book: everyone constantly worries about how they are seen by others. At first I wondered why his sentence about humiliation was virtually hidden in the last chapter of the book. But now I believe that he was aware of the distaste of most readers for shame. If he had flaunted the idea in the first chapter, the book might not have been a bestseller. The idea that shame issues are a virtually continuous presence in human affairs seems unthinkable in modern societies; modernity fosters the doctrine of individualism. We are taught that each person is a sovereign entity, self-reliant, standing alone. This emphasis is just a pipedream, since flourishing and even, to a large extent, surviving is dependent upon recognition and help from others. Individualism, and many other doctrines in modern societies, make it very difficult to deal directly with shame [5-12].

\section{A) Shame and Violence}

The psychiatrist James Gilligan (1997) proposed that most violence is caused by hidden shame. A prison psychiatrist for many years, he asked the prisoners convicted of murder why they did it. Their answers were surprisingly similar: "What did you expect me to do: he dissed me."

Gilligan's initial explanation of the way in which secret shame leads to violence is largely metaphorical: 
The degree of shame that a man needs to be experiencing in order to become homicidal is so intense and so painful that it threatens to overwhelm him and bring about the death of the self, cause him to lose his mind, his soul, or his sacred honor. (p. 110111). A more realistic model might be the building up of painful feeling by another of Gilligan's ideas, the spiraling of shame loops: I am ashamed that I am ashamed, toward infinity. The model of recursive loops proposed here explains how laminations and spirals of shame could lead to pain that feels unbearable.

Recently several historians and political scientists have at least hinted that humiliation might be a cause of war, in that revenge is driven by hidden shame. But most are cautious about an outright statement. In Hall's (2017) study, for example, the word shame is not used at all, but humiliation is mentioned 8 times. But not in the summaries at the beginning and end of the article, nor in the title. There are several writers in this area, but only a few take a stronger stance than Hall (See, for example, Löwenheim \& Heimann 2008 and Saurette 2006.) But even these more advanced studies don't take the step of relating humiliation to the shame literature.

Vengeance against the nation that defeated it has been considered one of the causes of war. During the last century this idea was often expressed in terms of the French word for revenge, Revanche. A recent example can be found in the book by Schivelbusch (2001) who uses the term frequently in his review of consequences of defeat (there 51 pages of discussion of revanche). My own book (1994) and recent article (with Daniel and Loe-Sterphone (2018) follow the same thread, suggesting that revenge is usually caused by the acting out unbearable shame. This theory is illustrated by an analysis of what seems to be the emotional origins of WWI and WWII. Judging from the success of Moisi's book, I am guessing that my earlier book and the other revenge studies are ignored because they dealt with a the single emotion of shame without first solving most reader's rejection of all emotions as causal. Moisi's book may take a crucial step in an extraordinarily important direction: changing our understanding of the causes of most wars. Perhaps it would be a step toward reducing the number and size of war in our time.

\section{References}

1. Gilligan J (1997) Violence: Reflections on a national epidemic. Vintage Books, New York, USA.

2. Goffman E (1959) Presentation of self in everyday life. Anchor, New York, USA.

3. Hall Todd (2017) On Provocation: Outrage, International Relations, and the Franco-Prussian War. Security Studies. November pp. 1-29.

4. Hall Todd, Andrew Ross (2015) Affective Politics after 9/11. International Organization. May, pp. 1 -14.

5. Kaufman Gershon (1989) The Psychology of Shame: Theory and Treatment of Shame-based Syndromes ( $2^{\text {nd }}$ edn.). Springer, New York, USA

6. Lacey David (2009) The Role of Humiliation in Collective Political Violence. University of Sydney, Sydney, Australia.

7. Löwenheim O, Heimann G (2008) Revenge in International Politics. Security Studies 17(4).

8. Dominique Moïsi (2009) The Geopolitics of Emotion: How Cultures of Fear, Humiliation, and Hope are Reshaping the World. Doubleday, New York, USA.

9. Saurette, Paul (2006) Humiliation and Post 9/11 Global Politics. Review of International Studies. 32, 3 (Jul.), pp. 495-522

10. Scheff, Thomas (1994) Bloody Revenge: Emotion, Nationalism and War. Westview Press (Reissued by iUniverse 2000), New York, USA.

11. Thomas Scheff, G Reginald Daniel, Joseph Loe-Sterphone (2018) A Theory of War and Violence. Aggression and Violent Behavior 39: 109115.

12. Schivelbusch, Wolfgang (2001) The Culture of Defeat. Fest Publishers, Berlin.

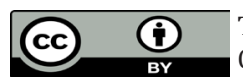

This work is licensed under Creative Commons Attribution 4.0 License

To Submit Your Article Click Here: Submit Article

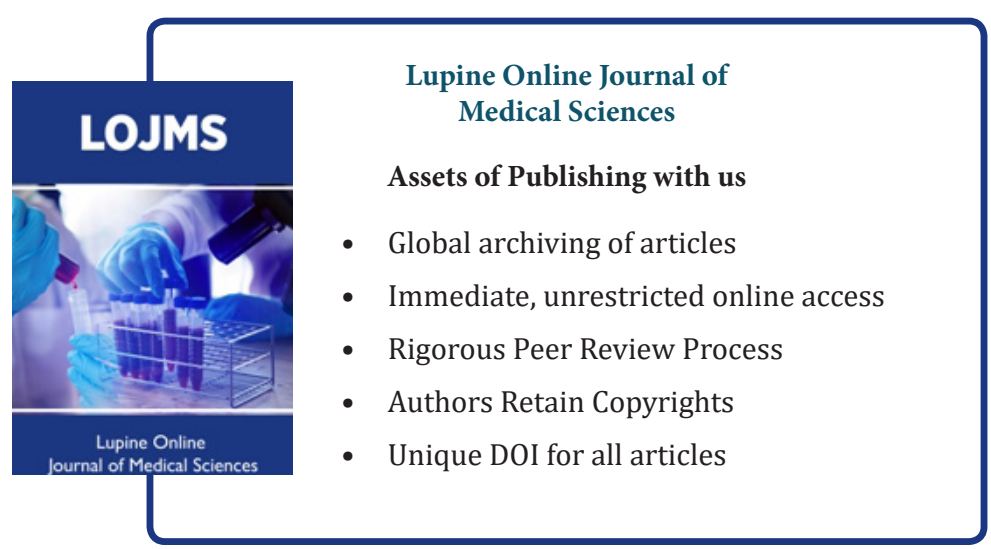

